\title{
PREVALENCE OF HUMAN PAPILLOMA VIRUS TYPES 16 AND 18 AMONG WOMEN WITH CERVICAL CANCER IN ALEPPO, SYRIA
}

\author{
AYMAN DANDAL, MOHAMMAD YASER ABAJY, MOUSTAFA ALKHALAF, ALI IBRAHIM \\ Department of Biochemistry and Microbiology, Faculty of Pharmacy, Aleppo University, Syria \\ Email: aliibrahim.jr@gmail.com
}

Received: 29 Mar 2017 Revised and Accepted: 19 Jun 2017

\section{ABSTRACT}

Objective: Cervical cancer is the second common type of cancer among women worldwide. Infection by certain types of human papillomavirus infection (HPV) such as HPV 16/18 has been considered as the most significant risk factor for the development of cervical cancer. This study was conducted to determine the prevalence HPV 16/18 in women with and without cervical cancer in Aleppo city, Syria.

Methods: Paraffin embedded cervical tissue samples were collected from 113 patients and 40 controls (normal cervix), DNA was extracted and analyzed by PCR for the presence of HPV16/18. Out of 113 cases of cervical carcinoma, 25 cases (22.1\%) were carcinoma in situ (CIS), 72 cases $(63.7 \%)$ were squamous cell carcinomas (SCC) and 16 cases (14.2\%) were adenocarcinoma (ADC)

Results: HPV 16 and/or 18 DNA was detected in 84 (74.3\%) cases out of 113 of cervical cancers, while it was found in only two of the 40 samples in the control group. At the same time, 9 out of 25 (36\%) carcinoma in situ, 61 out of $72(84.72 \%)$ squamous cell carcinomas, and 14 out of 16 (87.5\%) adenocarcinomas, were positive for HPV 16 and/or 18.

Conclusion: The frequency of infection with HPV 16 and 18 is high among Syrian women and a vaccine against these two types may be effective in about $74 \%$ of cervical cancers in Syria.

Keywords: Human papilloma virus (HPV), Cervical cancers, Genotype, HPV vaccination

(C) 2017 The Authors. Published by Innovare Academic Sciences Pvt Ltd. This is an open access article under the CC BY license (http://creativecommons.org/licenses/by/4.0/) DOI: http://dx.doi.org/10.22159/ijpps.2017v9i8.18773

\section{INTRODUCTION}

Cervical cancer is one of the most common malignancies among women worldwide [1]. The World Health Organisation (WHO) estimated that every year as many as 529,409 women worldwide are diagnosed with cervical cancer, and 274,883 die from the disease with the majority of cases and deaths occurring in developing countries [2,3]. The majority of cervical cancer cases are caused by persistent infection with certain types of HPV [4].

Over 170 types of HPV types have been identified [5], more than 50 of which typically infect the human anogenital tract [6]. On the basis of their association with cervical carcinogenesis, HPV genotypes are classified as either high risk (HPV16, 18, 31, 33, 35, 39, 45, 51, 52, 56, 58, $59,68,73,82$ ) or low risk (HPV6, 11, 40, 42, 43, 44, 54, 61, 70, 72, 81) [7]. The high-risk subtypes HPV 16 and 18 are responsible for $70 \%$ of cervical cancer cases [8]. However, the prevalence of specific HPV types in cervical cancer appears to vary geographically [9].

There are only a few studies on the HPV prevalence and genotype distribution in Syria [10,11], therefore more studies are needed to describe the distribution of HPV genotypes in cancer cases before these data can be generalised for application in national cancer screening and prevention strategies. The main aim of this study was to assess the prevalence of HPV infections and type distribution among the female population living in Aleppo, Syria and to investigate the impact of these infections on the development of diverse histological types of cervical carcinoma.

\section{MATERIALS AND METHODS}

\section{Clinical specimens}

This cross sectional study was conducted in Aleppo, north of Syria, between 2013 and 2015 and approved by the ethics committee of the University of Aleppo [Committee number: 1356 dated 06/01/2013]. All women who agreed to participate signed an informed consent form and answered a questionnaire on their clinical history.
Samples were formalin-fixed paraffin-embedded biopsies of 113 patients obtained from pathology departments of several Aleppo city hospitals. All cases were histopathologically confirmed cervical carcinoma consisting of carcinoma in situ (CIS) [N=25], squamous cell carcinoma (SCC) [N=72], adenocarcinoma (ADC) [N=16]. Controls with normal cervix $[\mathrm{N}=40]$ were matched to cases according to age. The ages of patients were between 34 to $73 \mathrm{y}$.

\section{DNA extraction}

For each of the cases, $20 \mathrm{mg}$ of tissue samples were prepared with standard microtome from every paraffin wax block and transferred into a microtube $(1.5 \mathrm{ml})$ avoiding any cross contamination between samples (using separate disposable items such as gloves, blades and tubes).

The Microtome blade was washed with xylene and ethanol to prevent cross contamination between the samples after sectioning of each block, triplicate. The area to be sectioned was examined carefully for the presence of tumor tissue and that an equal amount of tissue was included in each set. The tissue sections were then deparaffinised by xylene followed by ethanol wash to remove residual xylene.

DNA extraction was performed using QIAamp DNA mini kit (QIAGEN, Germany) according to the manufacturer's instructions. DNA was finally eluted with $100 \mu$ l of the elution buffer. The entire extracted DNA was stored at- $20{ }^{\circ} \mathrm{C}$ until PCR amplification was performed

\section{Polymerase chain reaction (PCR) amplification}

The amplification of high-risk HPV types in the tissues from cervical cancer patients was performed using high-risk HPV typing PCR kit (Sacace, Italy, Catalog No. V-12-100 R). This kit is a multiplex in vitro nucleic amplification test for genotyping of HPV types 16 and 18 in clinical specimens. It contains specific primers directed against 325 bp and $425 \mathrm{bp}$ fragments of the E6 region of HPV16 and HPV18 genome respectively. In addition, the kit includes primers directed against $\beta$-globin gene as an internal control. The positive control was 
validated using cervical carcinoma samples known to be positive for HPV types 16 and 18. Negative PCR control was included to ensure there was no cross contamination according to the manufacturer's protocol. Positive $\beta$-globin amplification proved that the sample contained a sufficient amount of DNA and that no PCR inhibitors were present. Samples processing before and after the amplification reactions were performed in strictly separated rooms to avoid contamination.

The PCR conditions were initial denaturation at $95^{\circ} \mathrm{C}$ for $5 \mathrm{~min}$. This step followed by denaturation at $95{ }^{\circ} \mathrm{C}$ for $15 \mathrm{~s}$, annealing at $65{ }^{\circ} \mathrm{C}$ for $25 \mathrm{~s}$, and elongation at $72{ }^{\circ} \mathrm{C}$ for $25 \mathrm{~s}$, and the process was repeated for 42 cycles. The final elongation step was prolonged at 72 ${ }^{\circ} \mathrm{C}$ for $1 \mathrm{~min}$ to ensure complete extension of the amplified product. Amplification products were visualised and photographed under UV light after electrophoresis through an agarose gel (2\%) containing ethidium bromide. The final results were read according to the size of the fragment.

\section{RESULTS}

In this study, formalin fixed paraffin embedded tissue sample of 113 patients with CIS, SCC or ADC of the cervix and 40 samples of controls who had normal cervix were tested for detection and typing of HPV. The mean age of the patient group was $49.49 \pm 7.665 \mathrm{y}$, whereas the mean age of the control group was $48.33 \pm 5.631$.

A total of $84(74.3 \%)$ patients' samples were positive for HPV DNA type 16 and/or 18 . Of these, 56 samples (66.6\%) were positive for HPV16, 18 samples (21.42\%) were positive for HPV 18 and 10 samples $(11.9 \%)$ were positive for both types (table 1, fig. 1). Among the control group, only two samples (5\%) were positive for HPV DNA (fig. 2).

At the same time, 9 out of 25 (36\%) CIS, 61 out of 72 (84.72\%) SCC, and 14 out of $16(87.5 \%)$ ADC, were positive for HPV16 and/or 18 (table 1). The highest numbers of HPV positive cases were from the 41-55 y age group (table 2).

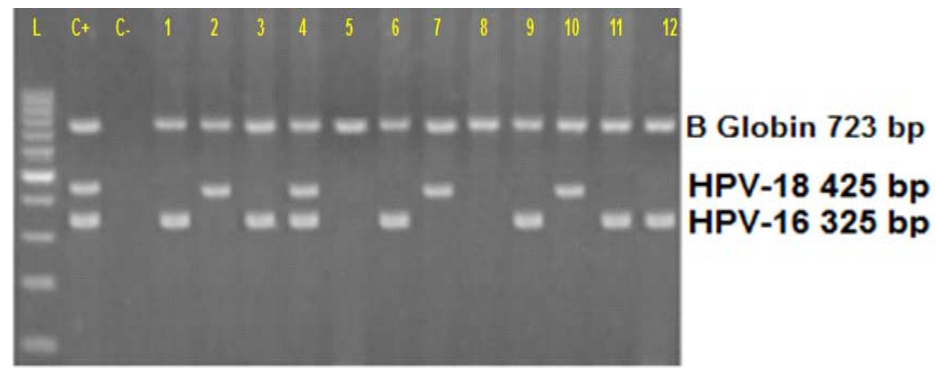

Fig. 1: Gel electrophoresis of HPV16/18 PCR products of 12 samples from patients group. L: ladder, C+: positive control, C-: negative control

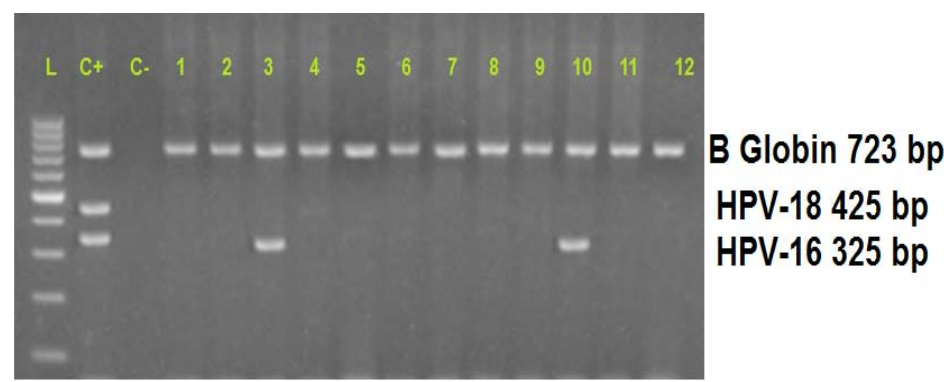

Fig. 2: Gel electrophoresis of HPV16/18 PCR products of 12 samples from controls group. L: ladder, C+: positive control, C-: negative control

Table 1: HPV16 and 18 distributions in patients with various cervical cancer types

\begin{tabular}{llll}
\hline Genotype & CIS, N=25 & SCC, N=72 & ADC, N=16 \\
\hline HPV 16 & $8(32 \%)$ & $44(61.11 \%)$ & $4(25 \%)$ \\
HPV 18 & $1(4 \%)$ & $13(18.05 \%)$ & $4(25 \%)$ \\
HPV 16 and 18 together & 0 & $4(5.55 \%)$ & $6(37.5 \%)$ \\
Total positive & $9(36 \%)$ & $61(84.71 \%)$ & $14(87.5 \%)$ \\
\hline
\end{tabular}

Table 2: Prevalence of HPV16 and/or 18 in patients and controls according to their Age

\begin{tabular}{|c|c|c|c|c|}
\hline Cancer type/control & $\leq 40$ y old & 41-55 y old & $56+y$ old & Total \\
\hline CIS & $3(2.65 \%)$ & $5(4.42 \%)$ & $1(0.88 \%)$ & $9(7.96 \%)$ \\
\hline SCC & $7(6.19 \%)$ & $40(35.4 \%)$ & $14(12.39 \%)$ & $61(53.98 \%)$ \\
\hline $\mathrm{ADC}$ & 0 & $5(4.42 \%)$ & $9(7.96 \%)$ & $14(12.39 \%)$ \\
\hline Control & 0 & $2(5 \%)$ & 0 & $2(5 \%)$ \\
\hline
\end{tabular}

\section{DISCUSSION}

Human cancer is a multifactorial disease which can develop through different biologic pathways. Many clinical and epidemiological studies have shown that infections by certain HPV types are causally linked to cervical cancer development [12]. The international biological study on cervical cancer showed that cervical cancers from 22 countries contained HPV DNA ranging from 75 to 100\% [13]. HPV 16 and 18 are 
among the high-risk HPV types recognised as the main causes of invasive cervical cancer and its precursor lesions [14].

Many studies have evaluated the prevalence of HPV in cervical cancer around the world, but the findings were inconsistent [15]. This study has evaluated the prevalence of the high-risk HPV types 16 and 18 in women with cervical cancer in Aleppo city, north of Syria.

There is only one study about the prevalence of HPV in cervical cancer in Syrian women, which investigated the presence of 7 Highrisk HPV types including HPV 16 and 18 in 44 cervical cancer samples which were not classified histologically [10]. Therefore, further studies with a larger number of samples are required to investigate the HPV prevalence in Syria.

Our current study showed that the DNA of HPV types 16 and/or 18 was detected in 84 out of 113 cervical cancer samples, giving an overall HPV prevalence of $74 \%$ of the samples. Similar detection rates of these two HPV types have been reported from Saudi Arabia [16], Algeria [17] and Mozambique 71.7\% [18]. On the other hand, the prevalence of HPV 16 and HPV 18 in the previous study from Syria was $88.6 \%(39 / 44)$ and the prevalence of all the 7 types detected in that study was $95.45 \%$ [10]. In addition, reports from different geographical regions showed different prevalence rates for HPV 16 and 18 such as in Malaysia [19], Sudan [20] and Uganda [21]. This may be explained by the difference in the number of samples, the type of samples, methods used in detection, the type of case group (high risk or low-risk groups) or cultural restrictions [22].

The results of this study showed that the prevalence of HPV 16 and HPV18 among the positive cases was $66.66 \%$ and $21.42 \%$ respectively. These incidence rates differ from the rates reported by Darnel et al. [10] which were $47.7 \%$ and $40.9 \%$ for HPV 16 and HPV 18 respectively. However, the distribution of these two HPV types in our study is quite similar to a report from Iran which showed HPV 16 and HPV18 prevalence of $60 \%$ and $22.2 \%$ respectively [23]. Similarly, the most prevalent HPV types found in a study from India were HPV 16 (66.7\%) followed by HPV 18 (19.4\%) [24]. In addition, several other reports showed that HPV 16 is more prevalent than HPV 18 [25-27]. However, different rates were reported in other studies from different countries [28-30].

The present study detected co-infection with HPV16 and 18 in $11.9 \%$ of the positive samples which is similar to results from other studies [31, 32]. However, various studies have reported different prevalence [12, 26]. The age group $41-55$ has been allocated the highest number of HPV positive cases in this study which is similar to results from other studies [31, 32].

The prevalence of HPV 16 and 18 among control women was 5\% which consistent with results from other studies [33]. On the other hand, the prevalence among control groups differ from one study to another and these differences are consistent with the wide variations of cervical cancer incidence rates [34].

Three histological types of cervical carcinoma i.e. carcinoma in situ (CIS), squamous cell carcinoma (SCC), and adenocarcinoma (ADC) were included in this study. Single infections due to HPV 16 and/or 18 occurred in $36 \%$ of cases of CIS, $84.71 \%$ cases of SCC and $87.5 \%$ cases of ADC. The prevalence of HPV 16 was $32 \%, 61.11 \%$ and $25 \%$ of CIS, SCC and ADC respectively, while HPV 18 occurred in 4\% of CIS, $18.05 \%$ of SCC and $25 \%$ of ADC. Co-infections with both types occurred in $5.55 \%$ of SCC and $37.5 \%$ of ADC but none of CIS cases were infected.

These results showed that a higher prevalence of HPV 16 in SCC than in the other two histological types while HPV 18 prevalence was higher in ADC than the other two types which is similar to the previously identified differences in HPV type distribution by histology [35, 36]. On the other hand, both HPV 16 and 18 were detected in equal frequency in ADC. This result was in accordance with reports from other countries [37, 38].

\section{CONCLUSION}

HPV 16 and/or 18 were detected in nearly $74 \%$ of cervical cancers in this study which indicates that the prophylactic vaccines against HPV 16 and 18 will be effective in preventing cervical cancer in a significant percentage of Syrian women. However, more comprehensive studies which investigate all high-risk HPV types and include a greater number of patients from different Syrian regions are recommended. Based on these studies, other high-risk HPV types might be included in the next generation of HPV prophylactic vaccine [39]. In addition, the results of such studies will help the authorities to introduce the strategies for the screening of cervical cancer and HPV vaccination[40]. It is also important to investigate all potential risk factors for a better understanding of cervical cancer development and protecting women against it.

\section{AUTHOR CONTRIBUTION}

Dandal A performed experiments, interpreted data and wrote the manuscript. Abajy MY, Alkhalaf M and Ibrahim A were involved in study design, developed the study method and protocol, and critically revised the manuscript.

\section{AFFILIATION}

Ayman Dandal, Mohammad Yaser Abajy, Moustafa Alkhalaf, Ali Ibrahim

Department of Biochemistry and Microbiology, Faculty of Pharmacy, Aleppo University, Syria

\section{CONFLICTS OF INTERESTS}

\section{Declared none}

\section{REFERENCES}

1. Kirti, Prabhakar PK. Human papilloma virus associated cervical cancer. Asian J Pharm Clin Res 2016;1 9:14-7.

2. Arbyn M, Castellsague X, de Sanjose S, Bruni L, Saraiya M, Bray $\mathrm{F}$, et al. Worldwide burden of cervical cancer in 2008. Ann Oncol 2011;22:2675-86.

3. WHO/ICO Information Centre on HPV and Cervical Cancer (HPV Information Centre). Human Papillomavirus and Related Cancers in World. Summary Report; 2010.

4. Shields TS, Brinton LA, Burk RD, Wang SS, Weinstein SJ, Ziegler $\mathrm{RG}$, et al. A case-control study of risk factors for invasive cervical cancer among US women exposed to oncogenic types of human papillomavirus. Cancer Epidemiol Biomarkers Prev 2004;13:1574-82.

5. De Villiers EM. Crossroads in the classification of papillomaviruses. Virology 2013;445:2-10.

6. Centurioni MG, Puppo A, Merlo DF, Pasciucco G, Cusimano ER, Sirito R, et al. Prevalence of human papillomavirus cervical infection in an Italian asymptomatic population. BMC Infect Dis 2005;5:77.

7. Nurun Nahar B, Shahina T, Munira J, Saif Ullah M, Afzal U. Genotyping of high-risk human papillomavirus (HPV) among cervical precancer and cancer patients. Acta Med Int 2015;2:19-28.

8. Brandstetter T, Böhmer S, Prucker O, Bissé E, zur Hausen A, AltMörbe J, et al. A polymerase based DNA biochip platform for human papillomavirus genotyping. J Virol Methods 2010;163:40-8.

9. Bosch FX, Burchell AN, Schiffman M, Giuliano AR, de Sanjose S, Bruni L, et al. Epidemiology and natural history of human papillomavirus infections and type-specific implications in cervical neoplasia. Vaccine 2008;26:1-16.

10. Darnel AD, Wang D, Ghabreau L, Yasmeen Y, Sami S, Akil N, et al. Correlation between the presence of high-risk human papillomaviruses and Id gene expression in syrian women with cervical cancer. Clin Microbiol Infect 2010;16:262-6.

11. Al Moustafa AE, Ghabreau L, Akil N, Alachkar A, Yasmeen A. High-risk HPVs and human carcinomas in the syrian population. Front Oncol 2010;4:68.

12. Bouvard V, Baan R, Straif K, Grosse Y, Secretan B, El Ghissassi F, et al. WHO international agency for WHO international agency for research on the cancer monograph working group: a review of human carcinogens-part b: biological agents. Lancet Oncol 2009;10:321-2.

13. Santos C, Munoz N, Klug SJ, Almonte M, Guerrero I, Alvarez M, et al. HPV types and cofactors causing cervical cancer in Peru. Br J Cancer 2001;85:966-71. 
14. Walboomers JM, Jacobs MV, Manos MM, Bosch FX, Kummer JA, Shah KV, et al. Human papillomavirus is a necessary cause of invasive cervical cancer worldwide. J Pathol 1999;89:12-9.

15. Bosch FX, Manos MM, Munoz N, Sherman M, Jansen AM, Peto J, et al. Prevalence of human papillomavirus in cervical cancer: a worldwide perspective International biological study on cervical cancer (IBSCC) study group. J Natl Cancer Inst 1995;87:796-802.

16. Al-Badawi IA, Al-Suwaine A, Al-Aker M, Asaad L, Alaidan A, Tulbah A, et al. Detection and genotyping of human papilloma virus in cervical cancer specimens from Saudi patients. Int J Gynecol Cancer 2011;21:907-10.

17. Hammouda D, Munoz N, Herrero R, Arslan A, Bouhadef A, Oublil $\mathrm{M}$, et al. Cervical carcinoma in algiers, algeria: human papillomavirus and lifestyle risk factors. Int J Cancer 2005;113:483-9.

18. Castellsague X, Klaustermeier J, Carrilho C, Albero G, Sacarlal J, Quint W, et al. Vaccine-related HPV genotypes in women with and without cervical cancer in Mozambique: burden and potential for prevention. Int J Cancer 2008;122:1901-4.

19. Sharifa Ezat WP, Sharifah NA, Sayyidi Hamzi AR, Norin Rahayu S. Prevalence of human papillomavirus genotypes in preinvasive and invasive cervical cancer-a UKM study. Med Health 2010;5:66-76.

20. Elasbali AM, El Din AHS, Abdallah RAH, Ahmed HG. Cervical and oral screening for HR-HPV types 16 and 18 among sudanese women cervical lesions. Infect Agents Cancer 2012;7:17.

21. Odida M, de Sanjosé S, Quint W, Bosch XF, Klaustermeier J Weiderpass E. Human papillomavirus type distribution in invasive cervical cancer in Uganda. BMC Infectious Diseases 2008;8:85.

22. Jumaah KA, Malla S, Kumar RS. Cloning and characterization of high risk human papilloma virus (HPV) oncogene E6. Asian J Pharm Clin Res 2014; 7:61-5.

23. Khodakarami N, Clifford GM, Yavari P, Farzaneh F, Salehpour S, Broutet $\mathrm{N}$, et al. Human papillomavirus infection in women with and without cervical cancer in Tehran, Iran. Int J Cancer 2012;131:156-61.

24. Sowjanya AP, Jain M, Rani Poli U, Padma S, Das M, Shah KV, et al. Prevalence and distribution of high-risk human papilloma virus (HPV) types in invasive squamous cell carcinoma of the cervix and in normal women in Andhra Pradesh, India. BMC Infect Dis 2005;22:116.

25. Rabelo S, Zeferino L, Villa I, Sobrinho J, Amarial R, Magalhaes A. Human papilloma virus prevalence among women with cervical intraepithelial neoplasia III and invasive cervical cancer from Goiania, Brazil. Mem Inst Oswaldo Cruz 2003;198:120-5.

26. Soma M, Kamaraj S. Detection of human papillomavirus in cervical grading by immunohistochemistry and typing of HPV 16 and 18 in high-grades by polymerase chain reaction. J Lab Physicians 2010;2:31-6.

27. Grace Nirmala J, Narendhirakannan RT. Detection and genotyping of high-risk HPV and evaluation of antioxidant status in cervical carcinoma patients in Tamil Nadu State, India-a case control study. Asian Pac J Cancer Prev 2012;12:2689-95.

28. Massad MS, Einstein MH, Huh WK, Katki HA, Kinney WK, Walter K, et al. 2012 updated consensus guidelines for the management of abnormal cervical cancer screening tests and cancer precursors. J Lower Genital Tract Disease 2013;17:S1S27.

29. Eslami G, Golshani M, Rakhshan M, Fallah F, Goudarzi H, Taghavi A. PCR detection and high-risk typing of human papillomavirus DNA in cervical cancer in iranian women. Cancer Ther 2008;6:361-6.

30. Clifford GM, Rana RK, Franceschi S, Smith JS, Gough G, Pimenta JM. Human papillomavirus genotype distribution in low-grade cervical lesions: comparison by geographic region and with cervical cancer. Cancer Epidemiol Biomarkers Prev 2005; $14: 1157-64$

31. Aldi Y, Trisnawati AN, Putra AE, Djamaan A. Detection of HPV type $45 \mathrm{~L} 2$ gene in cervical cancer patients by polymerase chain reaction method. Int J Pharm Pharm Sci 2015;7:129-32.

32. Castellsague X, Diaz M, de Sanjose S, Munoz N, Herrero R, Franceschi $\mathrm{S}$, et al. International agency for research on the cancer multicenter cervical cancer study group. Worldwide human papillomavirus etiology of cervical adenocarcinoma and its cofactors: implications for screening and prevention. J Natl Cancer Inst 2006;98:303-15.

33. Munoz N, Bosch FX, de Sanjose S, Herrero R, Castellsague X, Shah KV, et al. Epidemiologic classification of human papillomavirus types associated with cervical cancer. N Engl J Med 2003;348:518-27.

34. Saslow D, Solomon D, Lawson H, Killackey M, Kulasingam $\mathrm{SL}$, Cain J, et al. American cancer society, american society for colposcopy and cervical pathology, and american society for clinical pathology screening guidelines for the prevention and early detection of cervical cancer. Am J Clin Pathol 2012;137:516-42.

35. Smith JS, Lindsay L, Hoots B, Keys J, Franceschi S, Winer R, et al. Human papillomavirus type distribution in invasive cervical cancer and high-grade cervical lesions: a meta-analysis update. Int J Cancer 2007;121:621-32.

36. Clifford GM, Smith JS, Plummer M, Muñoz N, Franceschi S. Human papillomavirus types in invasive cervical cancer worldwide: a meta-analysis. Br J Cancer 2003;88:63-73.

37. Tenti P, Romagnoli S, Silini E, Zappatore R, Spinillo A, Giunta P, et al. Human papillomavirus types 16 and 18 infections in infiltrating adenocarcinoma of the cervix: PCR analysis of 138 cases and correlation with histologic type and grade. Am J Clin Pathol 1996;106:52-6.

38. Milde-Langosch K, Schreiber C, Becker G, Loning T, Stegner HE. Human papillomavirus detection in cervical adenocarcinoma by polymerase chain reaction. Hum Pathol 1993;24:590-4.

39. Sangar VC, Ghongane BB, Gupte R, Kesarkar R, Kalyan K, Chowdhary A. Comparison of post-licensure safety surveillance of bivalent and quadrivalent human papilloma virus vaccines in healthy mumbai women. Int J Pharm Pharm Sci 2015;7:437-42.

40. Rajanathan C, Lakshmikanth G, Agastian P. Evaluting the efficacy of aluminum phosphate formulated L2 based human papilloma virus vaccine. Asian J Pharm Clin Res 2015;8:199-201.

\section{How to cite this article}

- $\quad$ Ayman Dandal, Mohammad Yaser Abajy, Moustafa Alkhalaf, Ali Ibrahim. Prevelence of human papilloma virus types 16 and 18 among women with cervical cancerin aleppo, syria. Int J Pharm Pharm Sci 2017;9(8):90-93. 